\title{
Examining the Survival Strategies of Banks in Ghana in the Post - 2017 Banking Crisis
}

\author{
Kennedy Senyo Amenu - Tekaa \\ Department Of Economics and Law \\ Università di Macerata, Via Crescimbeni, 30, 62100, Macerata - Italy
}

\begin{abstract}
Financial crises affect many aspects of an economy. Ghana experienced an unprecedented banking crisis in 2017 which precipitated the Bank of Ghana and the Government taking clean up exercises to revamp the sector. Conversely, there's no evidence on the survival mechanisms adopted by individual banks post the crisis. Thus, objective of this study was to look into the survival strategies adopted by Ghanaian banks as they transitioned from the 2017 banking crisis to the post-crisis clean-up period. The study collected and analyzed data using a quantitative research approach. Eighty (80) bankers were chosen to participate in the study by completing a questionnaire. With the use of the Statistical Package for Social Sciences, descriptive statistics were utilized to present the findings. In addition, correlation and multiple linear regression were used to analyze the impact of strategy execution on the performance of the sampled banks using inferential statistics.According to the results of the study, there is a significant relationship between the various techniques used and the banks' performances. Product differentiation as an implemented strategy contributes most to the performance of banks. The implementation of effective survival strategies to increase banks' performance and drive organizational effectiveness was recommended by the study. Keywords: Survival strategies, Bank Performance, Financial crisis, Product differentiation, Corporate governance, Ghana
\end{abstract}

DOI: $10.7176 / \mathrm{RJFA} / 13-2-04$

Publication date: January $31^{\text {st }} 2022$

\section{Introduction}

The global financial crisis has been a hotly debated topic in recent years. Some experts prefer to refer to it as the most disastrous regulatory failure in contemporary history (e.g.: Buckley \& Arner, 2011). This type of crisis affects many aspects of an economy's life, progressing from a financial crisis to an economic difficulty, then to an employment problem, a social crisis, and a political crisis.

Many different academics, notably Helleiner (2011), have suggested that banks had a significant part in the formation of this global financial crisis due to their rather ubiquitous financial operations combined with a lack of appropriate government oversight of such activities.

Ivantsov (2016) postulated that survival strategies, (that is, a logical pattern of corrective and result-oriented measures) are executed incessantly to ensure that the banking and financial sectors, as well as businesses, overcome their hindrances to sustain and maintain their environment. This posits that the banking and financial sector organizations may have had survival strategies deployed to address numerous problems that they are exposed to internally and externally. Such strategies, according to Nothando et al. (2016), have the potential to improve banks' overall performance, providing them with a competitive advantage over their competitors. For example, Nothando et al. (2016) looked into the various survival tactics used by financial institutions in Zimbabwe following the dollarization of the economy from 2009 to 2015 . The study found that these institutions used strategies such as product uniformity, improved distribution channels, risk management, and technological innovation. Evidence reveals that a bank's adoption of a survival strategy is highly and positively connected to that institution's success (Nothando et al., 2016). This is the logic behind the order requiring, for example, all banks and financial institutions in Zimbabwe to diversify and create new products using technology. Furthermore, the Reserve Bank of Zimbabwe (RBZ) offers an incentive for banks by laying up a framework of monitoring and regulation to guarantee that they are not functioning in a hostile environment and that they employ the appropriate survival tactics (RBZ, 2014; Nothando et al., 2016).

In addition, other studies looked at whether it was more advantageous for banks and financial institutions to merge. In both Ghana and Nigeria, evidence abounds that banking industry mergers and acquisitions are more profitable for banks and also contribute to a shift away from the current crisis (Ikpefan, 2012). More specifically, Ogada et al. (2016) explored the extent to which diversification influences the financial performance of financial institutions in Kenya in order to lower the chance of a bank falling into a financial crisis and enhance their performance. Nonetheless, the analysis revealed no significant links between a bank's adoption of a survival strategy and its financial success. This implies that the question of survival strategy is not a black-and-white situation free of extraneous influences.

Ghana experienced a banking sector crisis in 2017 that resulted in the Bank of Ghana's clean-up efforts to revamp the financial sector of the economy via initiatives like recapitalization, consolidation, revocation of 
licenses, voluntary shutting down, and resolution of banks (Bank of Ghana, 2019; Obuobi et al., 2019). As noted by Nyalatorgbi (2019), the financial sector crisis has seen serious distress due to some banking institutions' having failed to achieve capital adequacy requirements, whereas others have had several non-performing loans causing capital losses. Again, it was observed that some financial institutions were insolvent and illiquid during the banking sector crisis period. According to Obuobi et al. (2019), the 2017 financial sector crisis in Ghana and the subsequent clean-up exercise were primarily caused by corporate governance challenges, false financial reporting, mischievous insiders' trading and banking activities, as well as a deterioration of the country's regulatory and supervisory framework.

The Bank of Ghana has offered some liquidity assistance to banking institutions bedeviled by the crisis since its inception and recounted the efficient means of resolving the crisis by addressing the core issues that culminated in the financial predicaments faced by the banking institutions (Bank of Ghana, 2019). This temporal and superficial fix to the problem has necessitated the recapitalization and implementation of more stringent regulatory policies to clean up the sector and ensure a more vibrant banking sector (Bank of Ghana, 2019). About twentythree (23) universal banking institutions have adopted some survival measures to attain the minimal capital requirement guideline of GHC400 million (Bank of Ghana, 2018). The banks' compliance with the new regulatory directive helps to consolidate gains in building a resilient banking sector and reposition the sector to adequately meet the highly diversified banking and capital investment needs of the Ghanaian economy. Also, compliance, coupled with internal survival strategies, assists in promoting alliances in the banking business through sustainable mergers and acquisitions by aligning robust corporate governance structures with risk management systems and practices (Obuobi et al., 2019).

Because Ghana's banks are still recuperating from the crisis, empirical research on the surviving methods used by the extant institutions appears to be lacking. The Bank of Ghana's decision to raise the minimum capital requirement for banks in Ghana has been explained as required to strengthen the banking industry and make it more robust to the changing requirements of the Ghanaian economy (Bank of Ghana, 2019). According to the Bank of Ghana's estimates, the recapitalization will enable amalgamation in the banking industry through sustainable mergers and acquisitions, as well as strong corporate governance structures and risk management systems. There also appears to be little empirical evidence of how banks in the nation have explored the above techniques for recovery following the consolidation phase.

As a result, the current study is being done in light of the fact that there is no empirical evidence to illustrate the survival tactics used by banks, as well as the effects of the Bank of Ghana's clean-up operation on those banks that remain in the system. There are still unresolved issues concerning the banks' economic, financial, and political survival plans in order to restore normalcy to their operations. Furthermore, the banking industry as a whole has yet to determine what particular actions were used to restore or erode public trust in the banking system. As a result, the goal of this research is to uncover the missing pieces that will provide clear empirical proof of survival strategies while also adding to the body of knowledge on the subject.

\subsection{Study Objectives}

General Objective

The general objective of this study was to examine the survival strategies adopted by Ghanaian banks in the transition from the 2017 banking crisis period to the post banking clean-up exercise.

Specific Objectives

The following specific objectives guided the study:

1. To identify the survival strategies adopted by banks in Ghana post the 2017 banking crisis.

2. To investigate the impact of survival strategies on the performance of banks in Ghana

\subsection{Literature Review}

\subsection{The Concept of Financial Crises}

A financial crisis can be defined in so many different ways, and hence it is quite difficult to determine a unified definition of the term. There were two schools of thought in the early literature on the financial crisis; one school of thought considered the financial crisis as a monetary phenomenon, while the other school of thought considered it as a wider phenomenon encompassing many different factors, as proposed by Kinleberger and Hyman Minsky. However, Mishkin believes that both schools of thought have flaws. The monetarists' view puts too much emphasis on the banking sector, while the Kindlebergers' and Minsky's view is also too broad. According to Mishkin, a reduction in the monetary base in the economy caused by a real financial crisis is the cause of the financial crisis (Mishkin, 1992, p. 116).

Mishkin then defines a financial crisis as follows:

"A financial crisis is a disruption to financial markets in which adverse selection and moral hazard become much worse, so that financial markets are unable to efficiently channel funds to those who have the most productive investment opportunities" (Mishkin, 1992, p. 117). 
It is becoming increasingly clear these days that financial crises or banking problems are caused by the depreciation of the value of the assets of the bank. Such a reduction in the value of the assets of the bank can be caused by the breakdown of real estate prices or the heightened numbers of bankruptcies in the non-financial sector. Another cause is when a government becomes uncommitted to paying its obligations (World Bank, 2016). Sometimes, governments give letters of credit to their contractors in order that they may have enough credit to complete their projects, yet the government delays, or sometimes fails, to pay the credit, leading to a sudden decrease in the value of bonds that are held by banks within their portfolios. Over time, the value of the assets reduces drastically, leaving banks with higher liabilities than assets. From that point on, the bank becomes insolvent or has negative capital (World Bank, 2016).

This means that when a bank is insolvent, it may have some capital, although that capital does not meet the minimum capital requirements set by the Central Bank. This situation is sometimes described as "technical insolvency" (World Bank, 2016). This was the case of UniBank in Ghana, which had a capital adequacy ratio of less than $5 \%$ (Bank of Ghana, 2018).

\subsection{Financial Crisis Difficulties and Root Causes}

First and foremost, it is critical to recognize that financial crises have the capacity to send economies into a tailspin and cause severe current account reversals. It has been noted in some regions of the world how transmissible particular crises may be, crossing boundaries and reaching other countries with no symptoms of susceptibility (World Bank, 2016). Furthermore, another source of the financial crisis is the implementation of unsustainable economy-wide policies. Massive current account deficits, unsustainable governmental indebtedness, excessive credit expansions, large capital inflows, and balance sheet delicacy are examples of such policies. While some financial crises are marked by currency and maturity mismatches, others are marked by banking sector off-balance sheet activity (World Bank, 2016). Caprio and Klingebiel (1996) and Laeven and Valencia (2012) from 1970 to 2011 identified around 147 financial crises that happened throughout the world over a forty-year period. According to these experts, there were 218 currency crises over this time period, as well as 66 sovereign debt crises. Attempting to foresee financial sector crises is a difficult undertaking. Cihák and Schaeck (2010), on the other hand, discovered certain characteristics that indicated a high chance of financial crises.

If governments wish to increase and safeguard public trust in deposits, they must guarantee the depositor's money either inherently or through a deposit insurance scheme (Claessens et al., 2011). This means that bank failure does not always result in a bank run. Insolvency happened and remained for a long length of time without being discovered during many different financial crises, according to Claessens et al. (2011). The issue only became apparent when it passed a certain point. Two separate channels of impacts have been proposed by various writers, each focusing on a different strand of financial market disruptions. To begin with, Aikman et al. (2019) believe the first of those two reasons to be financial system delicacy. This is due to the widespread occurrence of financial institutions taking too many risks and relying on "flimsy" wholesale funding, both of which frequently result in credit crunches and financial panic. Second, Aikman et al. (2019) suggest that low household expenditure is due to a rapid increase in household borrowing combined with the collapse of home prices.

According to a study by the Committee on the Global Financial System (2018), the banking sector's crisis uncovered certain extremely major flaws in banking systems and their regulatory frameworks. Although the storms have passed, this has had a detrimental influence on economic development, financial stability, and bank performance in a variety of ways and at various levels. Increased non-bank competition, globalization's dynamism, and technological innovations are among the issues highlighted by the Committee on the Global Financial System (2018) as barriers for banks.

In the instance of Ghana, KPMG, the official administrator of UniBank (after the Bank of Ghana withdrew the bank's license), looked through the business's assets and liabilities to see what alternatives were available for getting the bank back on track (Bank of Ghana, 2018; Frimpong, 2018). Significant corporate governance concerns, significant non-performing loans, inadequate risk management, compliance and management failures, as well as questionable financial transactions involving stakeholders and their associates, were uncovered by KPMG as some of the causes of the bank's demise. The bank's operations were discovered to be unsustainable, with insufficient income from interest and other sources to pay the expenses of borrowings and obligations, as well as roughly GH0.31 billion in annual overheads.

\subsection{The Concept of Survival Strategies of Bank}

A survival strategy is a set of activities implemented by businesses in order to overcome obstacles in their day-today operations and achieve long-term viability. This notion may be applicable to the banking industry in the sense that banks must have survival strategies in order to handle the environment they operate in, both internally and externally (Ebimobowei \& Ekankumo, 2012). This is critical for banks in particular, since it allows them to outperform their competitors. There are a number of reasons why banks must have sufficient capital at all times. One of these reasons is that it provides banks with a buffer in the case of a widespread decrease in cash flows 
(Bernanke, 2011). In addition, banks can avoid taking needless risks. When this phenomenon is compared to bank survival, it becomes clear that banks are unable to participate in hazardous ventures since capital is necessary to compensate for failure. Furthermore, a bank's capital serves as an insurance policy for not only that bank, but the whole banking industry. For this purpose, capital is a critical component of banking and bank sustainability. Again, inadequate corporate governance is a problem that plagues the banking sector across the world. Banks are responsible for ensuring effective corporate governance processes in order to safeguard consumer deposits. Depositors and bondholders are the ones who contribute to the bank's capital, yet decisions are made without their input. As a result, Becht et al. (2012) suggest that monetary authorities have tightened bank corporate governance concerns against this backdrop. Because of the demise of certain banks as a result of bad corporate governance, effective corporate governance has been proposed as a way for banks to survive (Mehran et al., 2011). According to Bernanke (2011), it is critical to rebuild public trust in the financial sector through excellent corporate governance. He also emphasizes the need for having appropriate and competent board members who are not involved in the day-to-day operations of the bank. Furthermore, it is critical that the board's dealings be as open as possible. In other words, banks must maintain excellent and effective governance systems within the constraints of the law in order to avoid management misbehavior.

Institutions can also thrive in a highly competitive environment if they can position themselves in areas where they have a competitive edge over their competitors. As a result, any firm's ability to achieve a competitive edge over competitors has been considered one of the most effective ways to do so. According to Martin-de Castrol et al. (2013), technical innovation is one approach for a company to obtain a competitive edge over its competitors. Some banks are able to stay afloat by merging with others or acquiring companies. On the other hand, mergers are typically thought to be a company's last resort for survival (Alam et al., 2014). Companies combine, acquire, or are acquired for a variety of reasons. When a company's life hangs on a knife's edge, it may consider a merger as a viable option for survival (Alam et al., 2014). It is worth mentioning that companies looking to acquire intellectual property might use mergers and acquisitions, particularly in the banking industry. Some businesses join to add value to their products and services, which is referred to as synergy value.

According to Gomes et al. (2012), companies that complement one another normally gain more when they merge. In various cases (Gomes et al., 2012), companies utilize mergers and acquisitions as a way of developing and expanding. According to Krishnamurthy and Vissing-Jorgensen (2012), some companies combine or buy other companies in order to enhance their market share. Mergers and acquisitions have the potential to propel companies into new markets, expand their distribution networks, or drive the launch of new product lines (Alam et al., 2014). Companies combine for a variety of reasons, including the need to survive in a highly competitive economy and obtain a competitive advantage over their competitors. The banking business is by far among the most competitive industries in any country, so merging or acquiring another financial firm is a wonderful choice when survival seems to be on the line.

Michael Porter proposed product differentiation as a primary universal approach for achieving competitive advantage in 1980. (Spencer et al., 2009). Simply said, product differentiation is the provision of something distinct for the market compared to what one's competitors are producing. It is a typical approach used by businesses to stay competitive in their respective industries. According to the literature, corporations view product diversification as a crucial technique for gaining a competitive advantage (see Barney, 2014). It may, however, be a highly costly plan for any company to implement. For example, De Loecker (2011) claims that companies that follow this method to establish a competitive edge over their competitors spend a lot of money on research and development. Different researchers use distinctive methods to determine how different a product or service is. However, the delivery of quality goods and services, changes in design, and the launch of new products, in addition to delivering distinctive product qualities, are all important criteria to gauge product differentiation for banks (AbuAliqah, 2012; Barney, 2014).

Outstanding customer service is, once again, a critical aspect for banks' survival in the industry. It is often regarded as a crucial business prerequisite (Zalatar, 2012). Service quality, according to Aliyu and Tasmin (2012), may be utilized as a tool for successful competition and is even more vital for a company's profitability and survival. Customer satisfaction and quality have been recognized by a number of experts as essential indices for determining an organization's competitiveness (see: Chakiso, 2015). As a result, businesses must refocus their efforts on customer pleasure as customers remain critical stakeholders. Customer service has been regarded as one of the most essential criteria in service marketing because of its telling impacts on consumers' repeat purchases (AlSudairi, 2012).

\subsection{Empirical Review}

Nyambura (2010) undertook a study to find out "what elements impact strategy change at the co-operative bank head office?" The senior management of the Cooperative Bank of Kenya was sampled, using the main office as a case study. One of the variables that affected the choice of strategic planning at the Cooperative Bank of Kenya's head office was the dynamics of the internal environment (which included human resources, financial resources, 
strategic planning, and organizational culture). The external elements that affected the firm's strategic planning, on the other hand, were economic and environmental. As a result of the research, the Cooperative Bank of Kenya's leadership should evaluate internal contextual challenges in order to develop better strategies for influencing change at the head office.

Again, Musyoka (2012) conducted research to determine the types of tactics used by Kenya Commercial Bank to obtain a competitive edge over its retail banking competitors. The data was acquired from Kenya Commercial Bank's senior management. The self-administered questionnaire was the most crucial technique for data gathering in the study. It also evaluated and presented its content analysis using descriptive statistics. According to the findings of the study, the Kenya Commercial Bank has implemented a number of methods to deal with various dangers and issues that may arise in the banking business. According to the report, Kenya Commercial Bank implemented techniques including T24's IT system, expanding coverage, and personnel training to build client loyalty through customer pleasure. It was also discovered that specific strategic marketing factors are used to fulfil the sector's competitive criteria. Developing new goods through market development and market emphasis are two of the strategic marketing factors.

Furthermore, Njagi and Kombo (2014) conducted research in Kenya to see how strategy execution affects banks' performance. Using a correlational research approach, the study addressed forty-three commercial banks in Kenya. In this study, the Pearson's correlation coefficient was used to establish the direction and strength of the link between strategy implementation and organizational performance. The study discovered a slightly strong link between strategy execution and organizational performance after creating a multiple regression model. As a result, the research concluded that if institutions wish to remain competitive, they must develop strategies.

Nothando et al. (2016) conducted a study in Zimbabwe between 2009 and 2015 to determine commercial banks' survival strategies after dollarization. Primary data was obtained via the use of questionnaires, while secondary data was gathered through the use of published journals and textbooks, using a descriptive study methodology. According to the study, commercial banks in Zimbabwe used methods including superior distribution networks, product diversification, technological innovation, and proper risk management. Political, economic, technological, and legal aspects were discovered to impact the operations of these institutions as well as their effective execution of strategy. Internally, the study discovered that resource availability, effective communication, organizational structure, and competent leadership all influenced bank plan execution. Furthermore, the study discovered a significant correlation between strategy and bank performance.

\subsection{Methodology}

This study adopted the quantitative methodological approach for addressing the study objectives. A total of eighty (80) banking staff from ten banks were sampled to respond to the study through the purposive sampling technique. Respondents were made up of branch managers, heads of departments, and operational staff. Data was collected from both primary and secondary sources. Primary data was collected by means of administered questionnaires, whereas secondary data was obtained from published audited annual reports and financial statements of the banks under study. Analysis of the data was performed to generate descriptive statistics in the form of percentages, means, and standard deviations. Data presentation was done using tables. Estimation was done by the use of the Statistical Package for Social Sciences (SPSS) version 24.0. Furthermore, the following regression model was applied to determine the relationship that exists between the implementation of the survival strategies and the performance of the banks.

The general regression model:

$Y t=\alpha+\beta_{1} \mathrm{XI}_{\text {it }}+\beta_{2} \mathrm{X} 2_{\mathrm{it}}+\beta_{3} \mathrm{X} 3_{\mathrm{it}}+\mathrm{B}_{4} \mathrm{X} 4_{\mathrm{it}}+\mathrm{B}_{5} \mathrm{X} 5_{\mathrm{it}}+\beta_{6} \mathrm{X} 6_{\mathrm{it}}+\mathrm{B}_{7} \mathrm{X} 7_{\mathrm{it}}+\mathrm{B}_{8} \mathrm{X} 8_{\text {it }}+\mathrm{u}_{\mathrm{it}}$

Where the various components of the regression model are defined as;

Where: $\mathrm{Y}=$ Return on Assets

$\alpha=\mathrm{y}$ intercept of the regression equation

$\mathrm{u}=$ The error term

$\mathrm{t}=$ Time (i.e., 2019-2020)

$\mathrm{i}=$ Number of Banks

$\beta 1, \beta 2, \beta 3, \beta 4, \beta 5, \beta 6, \beta 7$ and $\beta 8=$ are the regression coefficient

$\mathrm{X} 1$ = Adequate risk management, $\mathrm{X} 2=$ Quality customer service, $\mathrm{X} 3=$ Product innovation, $\mathrm{X} 4=$ Good corporate governance, $\mathrm{X} 5$ = Technological innovation, $\mathrm{X} 6$ = Extensive branch network, $\mathrm{X} 7$ =Good lending policy, $\mathrm{X} 8=$ Adequate capital

\subsection{Results And Discussion}

\subsection{Background Information of Respondents}

Respondents' background information was obtained using analysis of the frequencies of respondents in each of the demographic categories: gender, age, educational level, marital status, number of years with the bank, and position of each respondent. 
From Table I, it can be seen that out of the total number of 80 respondents, males dominated with $52 \%$.

Regarding the age of the respondents, the analyzed data revealed that most of the respondents were at their youthful ages; $60 \%$ of them were between the ages of 30 and 39 years. Again, $16 \%$ were in the age range of 40 49 years; $4 \%$ were above 50 years; and $20 \%$ were less than 29 years.

The information on education level indicates that up to $56.25 \%$ of the respondents possess a graduate degree, while $41.25 \%$ and $2.5 \%$ were postgraduate degree and higher national diploma degree holders respectively. This implies that the majority of the respondents had a minimum level of education that could enable them to give reliable responses.

Also, in terms of the number of years of working experience, it can be seen from Table I that, $42.5 \%$ respondents have worked in the banking field for ( 5 - 10 years); $31.3 \%$ ( 2 to 5 years); $17.5 \%$ (over 10 years); and only $8.8 \%$ have worked in the field for less than 2 years. This implies that the majority of the respondents were experienced enough to provide valuable responses pertaining to the survival strategies of banks.

Again, regarding the respondents' positions, it can be observed that $73.6 \%$ (59) of the respondents were operational staff, while $7.5 \%$ (6) were branch managers. It was further revealed that $10 \%(8)$ were sales executives, with the remaining $8.8 \%$ (7) of the respondents being departmental heads. This implies that the study focused on all the respective positions that are crucial for the survival of banks during the financial crisis.

Table I: Background information of the respondents

\begin{tabular}{|c|c|c|}
\hline Background Information & Frequency $(\mathbf{N})$ & Percentage (\%) \\
\hline \multicolumn{3}{|l|}{ Gender: } \\
\hline Male & 42 & 52 \\
\hline Female & 38 & 48 \\
\hline \multicolumn{3}{|l|}{ Age: } \\
\hline Less than 29 years & 16 & 20 \\
\hline $30-39$ years & 48 & 60 \\
\hline $40-49$ years & 13 & 16 \\
\hline 50 years and above & 3 & 4 \\
\hline \multicolumn{3}{|l|}{ Educational background: } \\
\hline Post Graduate Degree & 33 & 41.25 \\
\hline Graduate Degree & 45 & 56.25 \\
\hline Higher National Diploma & 2 & 2.5 \\
\hline \multicolumn{3}{|l|}{ Marital status: } \\
\hline Single & 33 & 42 \\
\hline Married & 44 & 55 \\
\hline Divorced & 3 & 3 \\
\hline \multicolumn{3}{|l|}{ Work experience (Years) } \\
\hline Less than 2 years & 7 & 8.8 \\
\hline 2 to 5 years & 25 & 31.3 \\
\hline 6 to 10 years & 34 & 42.5 \\
\hline Over 10 years & 14 & 17.5 \\
\hline \multicolumn{3}{|l|}{ Positions } \\
\hline Branch Manager & 6 & 7.5 \\
\hline Departmental Head & 7 & 8.8 \\
\hline Operational staff & 59 & 73.8 \\
\hline Others (sales executive) & 8 & 10.0 \\
\hline Total & 80 & 100.0 \\
\hline
\end{tabular}

Source: Survey data, 2021

\subsection{Survival Strategies Adopted by the Banks}

This section sought to understand the various survival strategies adopted by the sampled banks, in line with objective one. Using the five-point scale $(1=$ Not at all; $2=$ Rare occasion; $3=$ Sometimes; $4=$ Often; $5=$ All the time), respondents indicated the extent to which the following survival strategies are adopted by the bank. The study utilized mean $(X)$ and standard deviation $(S D$.) to denote the descriptive statistics.

In Table II data on bank survival strategies, product differentiation received the highest response $(X=4.5000$, $\mathrm{SD}=.57368)$. This was followed by the response that technological innovation was adopted $(\mathrm{X}=4.1250, \mathrm{SD}$ $=.93287)$. Quality of customer service was ranked third $(X=4.0750, \mathrm{SD}=.80779)$. Furthermore, respondents agreed on the implementation of a good lending policy $(\mathrm{X}=4.0625, \mathrm{SD}=.58122)$. Adequate risk management followed with $(X=4.0500, S D=.57147)$. Again, respondents agreed that good corporate governance was adopted $(\mathrm{X}=4.000, \mathrm{SD}=.69355)$. This was followed by an extensive branch network $(\mathrm{X}=3.9500, \mathrm{SD}=.72740)$. Finally, 
adequate capital $(\mathrm{X}=3.8000, \mathrm{SD}=.66371)$ was recorded as a survival strategy.

From the mean results presented, it can be observed that strategies such as product differentiation, technological innovation, quality customer service, good lending policy, adequate risk management, and good corporate governance were the strategies most widely adopted by the sampled banks. Nonetheless, "product differentiation" scored the highest mean response. As the majority of bank products remain homogeneous, the respondents indicated that developing new products which are different from the ones provided by other banks remains a powerful and unique strategy. They indicated that their respective banks have identified other means of reaching their customers. These include mobile banking, internet banking, agent recruitment, increasing the number of ATMs, merchant banking, etc.

The finding is in line with Nothando et al. (2016) studies which found product differentiation to be one major strategy implemented by banks in Zimbabwe. Also, the finding is consistent with Musyoka's (2012) study, which revealed certain strategic marketing variables such as developing new products, which are deployed by banks in order to meet the competitive standards in the sector. Again, the study results confirmed the findings of Dirisu et al. (2013) study in Ghana, which found IT advancement, competent staff, product differentiation, in addition to quality services, as major strategies deployed by Ecobank Ghana towards gaining competitive advantage.

\section{Table II: Survival Strategies Adopted by the Banks}

\begin{tabular}{lll}
\hline & Mean & Standard Deviation \\
\hline Product differentiation & 4.5000 & .57368 \\
\hline Technological innovation & 4.1250 & .93287 \\
\hline Quality customer service & 4.0750 & .80779 \\
\hline Good lending policy & 4.0625 & .58122 \\
\hline Adequate risk management & 4.0500 & .57147 \\
\hline Good corporate governance & 4.0000 & .69355 \\
\hline Extensive branch network & 3.9500 & .72740 \\
\hline Adequate capital & 3.8000 & .66371 \\
\hline
\end{tabular}

NB: Mean (where 1.00-3.00 = low adoption; 3.01-4.00=moderate adoption; and 4.01-5.00=high adoption Source: Survey data, 2021

\subsection{Inferential Statistics}

5.3.1 Correlation between Strategy Implementation and Banks' Performance

The data presented on the strategies implemented by the selected banks in Ghana were computed into single variables per factor by averaging each factor. Pearson's correlation analysis was then conducted at a $95 \%$ confidence interval and a 5\% confidence level, 2-tailed.

Table III indicates the correlation matrix between the various survival strategies being implemented and the performance of the banks. According to Table III, there is a positive relationship between the implementation of the survival strategies and the performance of the banks.

As evident from Table III, adequate risk management $(r=0.924, p=0.000)$, quality customer service $(r=$ $0.925, p=0.000)$, product differentiation $(r=0.946, p=0.000)$, technological innovation $(r=0.938, p=0.000)$, good corporate governance $(r=0.924, p=0.000)$, good lending policy $(r=0.939, p=0.000)$, adequate capital $(r$ $=0.941, p=0.000)$, reported a significant strong positive association with the performance of the banks, whereas extensive branch network $(r=-0.919, p=0.000)$. had a significant and strong negative association with the performance of the banks.

Hence, we can infer that a direct relationship exists between strategy implementation and the banks' performance, except for extensive branch network which shows an inverse relationship with the performance of the banks. This notwithstanding, all the strategies had a significant $p$-value $(p<0.05)$ at a 95\% confidence level. 
Table III: Relationship between strategy implementation and performance of the selected banks

\begin{tabular}{|c|c|c|c|}
\hline & & & Performance \\
\hline \multirow[t]{2}{*}{ Adequate risk management } & $\begin{array}{l}\text { Pearson's } \\
\text { Coefficient }\end{array}$ & Correlation & $0.924 * *$ \\
\hline & P-value & & 0.000 \\
\hline \multirow[t]{2}{*}{ Quality customer service } & $\begin{array}{l}\text { Pearson's } \\
\text { Coefficient }\end{array}$ & Correlation & $0.925 * *$ \\
\hline & P-value & & 0.000 \\
\hline \multirow[t]{2}{*}{ Product differentiation } & $\begin{array}{l}\text { Pearson's } \\
\text { Coefficient }\end{array}$ & Correlation & $0.946 * *$ \\
\hline & P-value & & 0.000 \\
\hline \multirow[t]{2}{*}{ Good corporate governance } & $\begin{array}{l}\text { Pearson's } \\
\text { Coefficient }\end{array}$ & Correlation & $0.924 * *$ \\
\hline & P-value & & 0.000 \\
\hline \multirow[t]{2}{*}{ Technological innovation } & $\begin{array}{l}\text { Pearson's } \\
\text { Coefficient }\end{array}$ & Correlation & $0.938 * *$ \\
\hline & P-value & & 0.000 \\
\hline \multirow[t]{2}{*}{ Extensive branch network } & $\begin{array}{l}\text { Pearson's } \\
\text { Coefficient }\end{array}$ & Correlation & $-0.919 * *$ \\
\hline & P-value & & 0.000 \\
\hline \multirow[t]{2}{*}{ Good lending policy } & $\begin{array}{l}\text { Pearson's } \\
\text { Coefficient }\end{array}$ & Correlation & $0.939 * *$ \\
\hline & P-value & & 0.000 \\
\hline Adequate capital & $\begin{array}{l}\text { Pearson's } \\
\text { Coefficient }\end{array}$ & Correlation & $0.941 * *$ \\
\hline
\end{tabular}

Correlation is significant at the 0.01 level (2-tailed).

Source: Survey data, 2021.

\subsection{Regression Analysis}

Regression analysis was also employed to examine the impact of strategy implementation on the performance of the banks.

The predictor variables deployed in the study were adequate risk management, quality customer service, product differentiation, good corporate governance, technological innovation, extensive branch network, good lending policy, and adequate capital. The performance of the banks symbolizes the criterion variable in the model.

From the findings, as illustrated in Table IV, the value of R-squared (coefficient of determination) was 0.965. This signifies that there was a variation of $96.5 \%$ in the performance of the banks due to changes in the predictor variables. This shows that $96.5 \%$ of the changes in the performance of the banks could be accounted for by changes in the survival strategies being implemented.

Moreover, the ANOVA in Table $\mathrm{V}$ shows the significance of the model by the value of $\mathrm{F}-$ statistics $(8,71)$ $=246.015, p=0.000$. This implies that the model is fit to predict the impact of strategy implementation factors on the performance of the banks.

Further, the size of the coefficient () for each independent variable gives the size of the effect that variable is having on the dependent variable, and the sign of the coefficient (positive or negative) gives the direction of the effect. Again, as shown in Table VI, the coefficients of adequate risk management (0.071), quality customer service (1.013), product differentiation (4.232), good corporate governance (1.144), technological innovation (0.056), good lending policy $(1.771)$, and adequate capital $(0.023)$ were positive, whereas the extensive branch network (0.968) was negative. This means that there is a positive relationship between strategy implementation and the performance of the banks, whereas extensive branch network has a negative relationship with the performance of the banks.

However, based on the statistical significance of the predictor variables, adequate risk management $(0.071$, $p=0.035)$, quality customer service $(1.013, p=0.007)$, product differentiation $(.232, p=0.000)$, good corporate governance $(1.144, p=0.022)$, technological innovation $(0.056, p=0.009)$, extensive branch network $(-0.968, p$ $=0.005)$, good lending policy $(1.771, p=0.000)$, and adequate capital $(0.023, p=0.045)$ were statistically significant in predicting a change in the performance of the banks at a significance level of 5\%). Beyond this level of significance (0.05), the variables do not make a significant contribution to the prediction of the dependent variable (Pallant, 2007). Therefore, we can infer that the survival strategies have a significant positive impact on the performance of the banks. 
Table IV: Model Summary

\begin{tabular}{lrrrrr} 
Model & R & \multicolumn{2}{c}{} & \multicolumn{2}{c}{ Std. Error of the } \\
Estimate
\end{tabular}

Source: Survey data, 2021.

a. Predictors: (Constant), Adequate capital, Product differentiation, Technological innovation, Quality customer service, Good lending policy, Good corporate governance, Extensive branch network, Adequate risk management

Table V: ANOVA Table

\begin{tabular}{llrcccc}
\hline Model & & Sum of Squares & df & Mean Square & F & Sig. \\
\hline 1 & Regression & 1338.598 & 8 & 167.325 & 246.015 & $.000^{\mathrm{b}}$ \\
& Residual & 48.290 & 71 & .680 & & \\
& Total & 1386.888 & 79 & & & \\
\hline
\end{tabular}

Source: Survey data, 2021

a. Dependent Variable: PERFORMANCE

b. Predictors: (Constant), Adequate capital, Product differentiation, Technological innovation, Quality customer service, Good lending policy, Good corporate governance, Extensive branch network, Adequate risk management

Table VI: Model analysis results

$\begin{array}{ll}\text { Dependent Variable }=\text { ROA } & \text { Wald Chi2 }=246.015 \\ & \text { R } 2=0.965 \\ (2019-2020) & \text { Prob }>F=8.71\end{array}$

\begin{tabular}{|c|c|c|c|c|c|}
\hline \multirow{2}{*}{ Model } & & \multicolumn{2}{|c|}{ Coefficients } & \multirow[b]{2}{*}{$\mathbf{t}$} & \multirow[b]{2}{*}{ Sig. } \\
\hline & & B & Std. Error & & \\
\hline & (Constant) & 4.642 & .951 & 4.880 & .000 \\
\hline & Adequate risk management & .071 & .871 & .082 & .035 \\
\hline & Quality customer service & 1.013 & .887 & 1.142 & .007 \\
\hline & Product differentiation & 4.232 & .275 & 15.399 & .000 \\
\hline & Good corporate governance & 1.144 & .489 & 2.340 & .022 \\
\hline & Technological innovation & .056 & .100 & .557 & .009 \\
\hline & Extensive branch network & -.968 & .571 & -1.694 & .005 \\
\hline & Good lending policy & 1.771 & .319 & 5.545 & .000 \\
\hline & Adequate capital & .023 & .312 & .075 & .045 \\
\hline & a. Dependent & & & & \\
\hline & PERFORMANCE & & & & \\
\hline
\end{tabular}

\section{Source: Survey data, 2021}

$Y t=\alpha+\left(\beta_{1} \mathrm{XI}_{\mathrm{it}}+\beta_{2} \mathrm{X} 2_{\mathrm{it}}+\beta_{3} \mathrm{X} 3_{\mathrm{it}}+\mathrm{B}_{4} \mathrm{X} 4_{\mathrm{it}}+\mathrm{B}_{5} \mathrm{X} 5_{\mathrm{it}}+\beta_{6} \mathrm{X} 6_{\mathrm{it}}+\mathrm{B}_{7} \mathrm{X} 7_{\mathrm{it}}+\mathrm{B}_{8} \mathrm{X} 8_{\mathrm{it}}+\mathrm{u}_{\mathrm{it}}\right)$ becomes:

$\mathrm{Yt}=4.642+(0.071 \mathrm{X} 1+1.013 \mathrm{X} 2+4.232 \mathrm{X} 3+1.144 \mathrm{X} 4+0.056 \mathrm{X} 5-0.968 \mathrm{X} 6+1.771 \mathrm{X} 7+0.023 \mathrm{X} 8+\mathrm{u})$

The regression equation above has established that, taking all factors into account (adequate risk management, product innovation, product differentiation, quality customer service, good corporate governance, good lending policy, technological innovation, and adequate capital) constant at zero, the performance of the banks will be 4.642. Taking all other independent variables to zero, the findings show that a unit increase in adequate risk management leads to a 0.071 increase in bank performance, a unit increase in quality customer service leads to a 1.013 increase in bank performance, a unit increase in corporate governance leads to a 1.144 increase in bank performance, and a unit increase in technological innovation leads to a 0.056 increase in bank performance. The findings suggest that product differentiation as an implemented strategy contributes most to the performance of the banks with a 4.232 increase for every unit increase.

The findings support Akinyele and Fasogbon's (2010) argument that for a firm to survive a crisis, the primary objective is to create and implement a formal strategic planning to improve that firm's performance. However, having an extensive brank network increases the overhead costs since banks would be skimping on their resources, particularly during crisis periods. Planning strategically helps firms improve their overall performance in their dealings. Naidoo (2010) postulates that strategic planning is meant to better position a firm in the market to enhance effective performance. In addition, firms that plan strategically inherently provide a well-defined direction and streamline their activities to achieve their primary purpose. Furthermore, Colwell and Joshi (2013) argue that when firms are able to successfully implement their strategies, they benefit from improved performance as a result of the well implemented strategy. Moreover, Wachira (2013), Njagi and Kombo (2014), and Nothando et al. (2016) 
studies found a strong relationship between strategy implementation and organizational performance.

\section{Conclusion And Recommendations \\ 6.1 Conclusion}

This study provided empirical evidence on post-financial-crisis bank survival strategies in Ghana. Banks need to have a survival strategy that combats various challenges at both internal and external levels. These strategies have the tendency to increase the general performance of banks, giving them a competitive edge over their rivals.

Based on the study findings, the researcher makes the following conclusions:

The study revealed some survival strategies being highly implemented by the sampled banks, including: Product differentiation, Technological innovation, Quality customer service, good lending policy, Adequate risk management, and Good corporate governance. From these strategies, Product differentiation was found to be the most highly implemented survival strategy by the sampled banks. Thus, it can be concluded that the sampled banks have a more competitive advantage over other banks that are not adopting these survival strategies. Furthermore, the high adoption of these survival strategies by the sampled banks has a significant impact on the banks' performance, as confirmed by the study.

Also, the study revealed Adequate capital to be the survival strategy with the lowest adoption by the sampled banks. This could be because of the inability of the individual banks to adhere to the capital adequacy policy directive, as well as weak enforcement of capital adequacy policies by management.

Furthermore, it can be concluded that the banking sector is faced with several policies that may be too stringent or unfavourable. For instance, regarding the issue of capital adequacy for banks, policies and regulations on minimum capital requirements for banks pose a significant threat to the banking sector, hence the difficulty of the banks' effectively adhering or complying with it.

\subsection{Recommendations}

In line with the study's findings and conclusion, the following recommendations are made:

First and foremost, the study found a significant positive relationship between the strategies implemented (quality customer service, adequate risk management, product innovation, technological innovation, good corporate governance, good lending policy, as well as adequate capital) and the performance of the banks. Hence, it is recommended that the management of the various banks continue to implement and also identify other survival strategies that would help to increase the banks' performance, particularly during crisis situations.

Furthermore, the study recommends that banks focus on differentiating their products through marketing to achieve bank competitiveness. Marketing improves bank sales, and also leads to the designing of customized financial products that meet customer expectations. The study recommends that banks consider the quality-ofservice delivery. Again, management of banks should be committed to improving the quality of their products to suit different market needs so as to attract more customers and increase their customer base.

Again, banks in Ghana, including the sampled banks, are recommended to continuously invest in future technological innovations as an effective way of gaining competitive advantage as well as maximizing their profits.

Moreover, it is recommended that the boards of directors of individual banks should ensure good and effective governance practices within the confines of the law in order to avoid management malfeasance. They should ensure that the banks effectively adhere to sector policies.

In terms of policy, it is recommended that policies and regulations on capital adequacy by banks in Ghana should be periodically reviewed to reflect current economic trends globally and at the in-country level, so that the policies and regulations are not too stringent on the banks to ensure effective adherence. This would in turn provide cushioning for the banks in the event of a general reduction in cash flows, promote protection of depositors' money, and enhance depositors' confidence in the banking sector.

To conclude, the significant positive relationship established between the survival strategies and the banks' performance indicates the need for firms to maintain a balance between the variables.

\section{References}

Abu Aliqah K., M. (2012). Differentiation and Organizational Performance: Empirical Evidence from Jordanian Companies. Journal of Economics, (3)1.

Aikman, D., Bridges, J., Kashyap, A., \& Siegert, C. (2019). Would macroprudential regulation have prevented the last crisis? Journal of Economic Perspectives, 33(1), 107-30.

Akinyele, S. T., \& Fasogbon, O. I. (2010). Impact of strategic planning on organizational performance and survival. Research Journal of business management, 4(1), 73-82.

Alam A., Khan, S. \& Zafar, F. (2014). Strategic Management: Managing Mergers and Acquisitions. International Journal of BRIC Business Research (IJBBR), 3(1). 
Aliyu, A. A., \& Tasmin, R. B. H. J. (2012). The impact of information and communication technology on banks' performance and customer service delivery in the banking industry. International Journal of Latest Trends Finance and Economy, 2(1), 80-90.

AlSudairi, M. A. T. (2012). E-service quality strategy: Achieving customer satisfaction in online banking. Journal of Theoretical and Applied Information Technology, 38(1), 6-24.

Bank of Ghana (2018) Annual Report Retrieved June 2, 2021 from https://www.bog.gov.gh/wpcontent/uploads/2019/07/AnnRep-2018.pdf

Bank of Ghana (2019). Retrieved June 2, 2021, from https://www.graphic.com.gh/images/pdfs/BoG_Press_Release_Update_on_Banki_Sector_Reforms.pdf

Barney, J. B. (2014). Gaining and sustaining competitive advantage. Pearson higher ed.

Becht, M., Bolton, P., \& Röell, A. (2011). Why bank governance is different. Oxford review of economic policy, 27(3), 437-463.

Bernanke, B. S. (2011). Global imbalances: links to economic and financial stability: a speech at the Banque de France Financial Stability Review Launch Event, Paris, France, February 18, 2011 (No. 563).

Buckley, R., \& Arner, D. (2011). From crisis to crisis: the global financial system and regulatory failure. Kluwer Law International BV.

Caprio, G., \& Klingebiel, D. (1996, April). Bank insolvency: bad luck, bad policy, or bad banking? In Annual World Bank conference on development economics (Vol. 79).

Chakiso, C. B. (2015). The effect of relationship marketing on customers' loyalty (Evidence from Zemen Bank). EMAJ: Emerging Markets Journal, 5(2), 58-70.

Claessens, S., Pazarbasioglu, C., Dobler, M. C., Laeven, L., Nedelescu, O., Valencia, F., \& Seal, K. (2011). Crisis management and resolution: Early lessons from the financial crisis. Staff Discussion Notes, 2011(005).

Colwell, S. R., \& Joshi, A. W. (2013). Corporate ecological responsiveness: Antecedent effects of institutional pressure and top management commitment and their impact on organizational performance. Business Strategy and the Environment, 22(2), 73-91.

Committee on the Global Financial System. (2018). Structural changes in banking after the crises. CGFS Papers. No 60. January. 125 pgs

De Loecker, J. (2011). Product differentiation, multiproduct firms, and estimating the impact of trade liberalization on productivity. Econometrica, 79(5), 1407-1451.

Dirisu, J. I., Iyiola, O., \& Ibidunni, O. S. (2013). Product differentiation: A tool of competitive advantage and optimal organizational performance (A study of Unilever Nigeria PLC). European Scientific Journal, 9(34).

Ebimobowei, A., \& Ekankumo, B. (2012). Customers service strategy and commercial banks survival in a postconsolidation era in Nigeria. American International Journal of Contemporary Research, 2, 142-53.

Frimpong, E. D. (2018). BoG collapses 5 banks into Consolidated Bank Ghana Ltd. Daily Graphic.1st August 2018. Available at https://www.graphic.com.gh/business/business- news/bog-collapses-5-banks-intoconsolidated-bank-ghana-ltd.html (Accessed: 21 st January 2019)

Gomes, E., Angwin, D., Peter, E., \& Mellahi, K. (2012). HRM issues and outcomes in African mergers and acquisitions: a study of the Nigerian banking sector. The International Journal of Human Resource Management, 23(14), 2874-2900.

Helleiner, E. (2011). Understanding the 2007-2008 global financial crisis: Lessons for scholars of international political economy. Annual review of political science, 14, 67-87.

Ikpefan, O. A. (2012). Issues in banking and finance. The Chartered Institute of Bankers of Nigeria.

Ivantsov, E. (2016). Heads or tails: financial disaster, risk management and survival strategy in the world of extreme risk. Routledge, New York, USA

Krishnamurthy, A., \& Vissing-Jorgensen, A. (2012). The aggregate demand for treasury debt. Journal of Political Economy, 120(2), 233-267.

Laeven, L., \& Valencia, F. (2012). Systemic banking crises database: An update. IMF working paper 12/163

Martín-de Castro, G., Delgado-Verde, M., Navas-López, J. E., \& Cruz-González, J. (2013). The moderating role of innovation culture in the relationship between knowledge assets and product innovation. Technological Forecasting and Social Change, 80(2), 351-363.

Mehran, H., Morrison, A. D., \& Shapiro, J. D. (2011). Corporate governance and banks: What have we learned from the financial crisis? FRB of New York Staff Report, (502).

Minsky, H. (1992): The financial instability hypothesis, Levy Economics Institute Working Paper No. 74, Levy Economics Institute.

Mishkin, F. S. (1992). Anatomy of a financial crisis. Journal of evolutionary Economics, 2(2), 115-130.

Musyoka, J. L. (2012). Competitive strategies adopted by Kenya Commercial Bank limited in retail banking. Unpublished MBA Project, School of Business, University of Nairobi.

Naidoo, V. (2010). Firm survival through a crisis: The influence of market orientation, marketing innovation and business strategy. Industrial marketing management, 39(8), 1311-1320. 
Nderu, J. M. (2014). Strategic management practices at mentor savings and credit co-operative society ltd in Murang'a, Kenya (Doctoral dissertation, University of Nairobi).

Njagi, L., \& Kombo, H. (2014). Effect of strategy implementation on performance of commercial banks in Kenya. European Journal of Business and Management, 6(13), 62- 67.

Nothando, T., Nyasha, K., \& Kaduwo, T. (2016). A Critical Analysis of the Survival Strategies Used by Commercial Banks in Zimbabwe Post Dollarization (2009-2015). Global Journal of Commerce and Management Perspectives, 5(6), 6-15

Nyalatorgbi, E. (2019). Bank of Ghana closes seven banks in banking crisis. African Agenda, Third World Network Africa, 21(3), 33-36

Nyambura, K. C. (2010). Factors Influencing Strategic Change at the Co-Operative Bank of Kenya Head Office (Doctoral dissertation).

Obuobi, B., Nketiah, E., Awuah, F., \& Amadi, A. G. (2019). Recapitalization of banks: Analysis of the Ghana banking industry. Open Journal of Business and Management, 8(01), 78.

Ogada, A., Achoki, G., \& Njuguna, A. (2016). Effect of diversification on the financial performance of merged institutions. Murang'a University of Technology, School of Business and Economics.

Ogutu, M., \& Nyatichi, V. (2012). Competitive strategies adopted by multinational banks in Kenya. DBA Africa Management Review, 2(1), 98-109.

Reserve Bank of Zimbabwe (RBZ) (2014). Monetary Policy Statements. Reserve Bank of Zimbabwe.

Spencer, X.S., Joiner, A.T. and Salmon, S. (2009), 'Differentiation Strategy, Performance Measurement Systems and Organizational Performance: Evidence from Australia'. International Journal of Business, (14)1.

Wachira, E. W. (2013). The effect of technological innovation on the financial performance of commercial banks in Kenya (Doctoral dissertation, University of Nairobi).

World Bank (2016). Banking Crises. Available at http://www.worldbank.org/en/publication/gfdr/gfdr2016/background/banking-crises University of Ghana http://ugspace.ug.edu.gh.

Zalatar, W. F. (2012). Quantifying customers' gender effects on service quality perceptions of Philippine commercial banks. Procedia-Social and Behavioral Sciences, 57, 268-274. 